\title{
O PODER REGULADOR DAS AGÊNCIAS REGULADORAS E AS GARANTIAS DEMOCRÁTICAS: QUESTÕES CRÍTICAS
}

\author{
Fernando de Brito Alves* \\ Juan Roque Abilio ${ }^{* *}$
}

\begin{abstract}
RESUMO
O presente trabalho procura problematizar o papel das agências reguladoras no sistema democrático brasileiro. Assim, ante a inegável intervenção dessas agências na sociedade, indaga-se se há ofensa à democracia, tendo em vista que no exercício da atividade regulamentar invariavelmente elas substituem o parlamento, refletindo-se, ademais, qual a verdadeira função das agências reguladoras no Brasil. Também se busca analisar se o Estado Brasileiro é ou não um Estado Regulador. Além de questões de ordem teórica, traz o presente, questões de ordem prática e procura ser ainda mais audacioso ao cotejar possíveis formas de empoderamento da sociedade na busca de controle das agências, galgando sempre para uma maior participação popular a fim de democratizar as agências reguladoras. $\mathrm{O}$ método utilizado foi a pesquisa bibliográfica, além do levantamento de dados sobre a atuação das Agências Reguladoras.
\end{abstract}

PALAVRA-CHAVES: Agências reguladoras. Democracia. Participação popular.

\begin{abstract}
This paper seeks to problematize the role of regulatory agencies in the Brazilian democratic system. Thus, in the face of the undeniable intervention of these agencies in society, it is questioned if there is an offense against democracy, since in the exercise of regulatory activity they invariably replace the parliament, reflecting, in addition, what the true function of the regulatory agencies in Brazil. It also seeks to analyze whether or not the Brazilian State is a
\end{abstract}

\footnotetext{
* Pós-doutor em Democracia e Direitos Humanos pela Universidade de Coimbra. Coordenador do Mestrado e Doutorado em Ciência Jurídica da Universidade Estadual do Norte do Paraná.

** Pós-graduando em Direito do Estado pela PROJURIS-FIO.
} 
Regulatory State. Besides issues of a theoretical nature, it brings the present, questions of a practical nature, and seeks to be even more audacious in comparing possible forms of empowerment of society in the search for control of agencies, always striving for greater popular participation in order to democratize the regulatory agencies . The method used was the bibliographical research, besides the data collection on the performance of the Regulatory Agencies.

KEYWORDS: Regulatory agencies. Democracy. Popular participation.

\section{INTRODUÇÃO}

Sabe-se que em um Estado Democrático de Direito, as decisões mais importantes para o futuro da sociedade devem partir de um órgão legitimado para tanto. No caso brasileiro este órgão é o Poder Legislativo, o qual possui em sua composição os representantes do povo, cujas decisões para o futuro da sociedade são tomadas, ou assim se espera, de forma democrática.

Logo, o brocardo de que todo poder emana do povo se cumpre - não de forma exaustiva, mas sim em uma das suas formas de cumprimento - em votações democráticas por representes desse povo que são eleitos periodicamente para realizar tal mister.

Desse modo o Estado deve garantir que a titularidade do poder nunca saia da sociedade, pois é o Estado que serve a sociedade e não o revés.

Por essas razões é que se torna enigmática a atuação das agências reguladoras, que devido a uma produção, por diversas vezes, até maior que o próprio Legislativo, interfere, inevitavelmente, nas relações pessoais, ou seja, as agências reguladoras que não possuem representante do povo, por diversas vezes, se mostram na dianteira da tomada de decisões importantíssimas para o futuro da sociedade, quebrando assim a lógica da democracia que rege nosso Estado.

Por consequência, entender a legalidade e a constitucionalidade da função das agências, seus limites e sua legitimidade é essencial para uma análise pragmática da regulação que elas trazem, sempre lembrando que se deve analisar toda e qualquer norma ou regulamento não de forma isolada, mas sim 
entendendo-as como parte de um conjunto de normas.

Por exemplo, ao analisar algum regulamento expedido pelo Banco Central (BACEN) o intérprete deve levar em consideração não o regulamento de forma isolada, mas como parte de um conjunto do direito, em especial modo a Constituição, o Código de Defesa do Consumidor e o Código Civil.

Todavia, entender quais são os limites e o que seria o ato de regulamentar é um desafio no qual se encontra presente em todas as linhas deste trabalho e o pior de tudo, o desgaste que já se chega é ter em mente que este trabalho não se encontra finalizado, pois, somente com o estudo aqui exposto e juntamente com casos práticos é que se construirá o verdadeiro entendimento dos limites de atuação das agências reguladoras.

É também pretenso o presente artigo em analisar a evolução do Estado e refletir se o Estado brasileiro é um Estado Regulador. Tal reflexão se mostra justificável tendo em vista que entender a relação do Estado e Sociedade, em especial a sua atuação na economia, é essencial para uma análise conclusiva do tema aqui proposto e para compreender qual a função que as agências reguladoras devem tomar perante a Sociedade.

Notório que no momento em que se escreve este artigo, mês de julho de dois mil e dezessete, há infelizmente uma crise entre os poderes, e drasticamente a sociedade vive em uma tensão com a Democracia, assim, deve-se deixar claro, que não pretende o presente trabalho, mesmo que parece em um primeiro momento, agigantar o Poder Judiciário, mas sim ter um pensamento utópico e sonhador de um Judiciário que sirva como ponte de empoderamento da sociedade e não como um tirano que infelizmente está cada dia mais se mostrando frente a determinadas ideologias políticas e sociais.

Dessa forma este trabalho busca fomentar a discussão acerca da juridicidade dos atos expedidos pelas agências reguladoras, pois sua importância é inegavelmente reconhecida e sentida por toda a sociedade brasileira.

Para tanto, inicialmente se discutirá o fenômeno denominado descentralização administrativa, visto que as agências reguladoras são parte da chamada Administração Indireta.

Aprofundando o tema irá se discutir a descentralização autárquica, a qual surge ante ao fato da necessidade de se atribuir 
mais poderes às pessoas da Administração Indireta, mostrando quais são suas funções e suas necessidades para o Estado.

Depois, mesmo que rapidamente, irá se fazer uma diferença entre agência executiva e reguladora, voltando-se, a partir de então, a focar de forma principal e única nas agências reguladoras, pois, por amor à brevidade não serão gastas muitas linhas nas agências executivas, todavia, que isto não seja interpretado como forma de diminuir sua importância.

O tópico mais alargado e de mais importância é o seguinte o qual traz a reflexão sócio-político do Brasil, refletindo-se se ele é um Estado Regulador ou não, neste tópico irá armar o leitor da base teórica e dogmática, a qual irá desempenhar o papel de lente para a análise do Estado na economia, em especial modo irá trazer qual a verdadeira perspectiva e modo de atuação que deverá ter as agências reguladoras na sociedade, dando assim, substrato teórico para todas as críticas a serem aventadas neste trabalho.

Para o presente estudo também foi necessário trazer uma breve comparação ao modelo americano, tendo em vista que toda a regulamentação foi de grande inspiração norte americana. Dessa forma, entender como que surgiram as agências reguladoras nos Estados Unidos, bem como sua função frente àquela sociedade é armar ainda mais o presente trabalho de argumentos para as críticas que serão levantadas frente à atuação prática que se verifica diuturnamente, em especial modo frente aos abusos cometidos em desfavor da sociedade.

Depois de tanta circunscrição ao tema, que o é necessário para armarmos de argumentos dogmáticos sobre o assunto, é que se chegará ao ponto fulcral do presente trabalho, a análise da competência das agências reguladoras, em especial modo seus limites e suas críticas.

Encontra-se, também, no presente trabalho a diferença entre a função regulamentar e reguladora, cujas diferenças não nos apegamos, pois, o presente trabalho mostra-se muito mais focado nas questões democrática e teóricas das agências reguladoras e não em questões de ordem técnica.

As críticas que outrora foram feitas de forma sutil a partir do tópico ... encontram-se mais acirradas, trazendo um tópico no qual se critica a formação das regulamentações das agências e afirmando 
categoricamente a necessidade de se trazer maior legitimidade democrática na atividade delas, pois, conforme cansativamente irá se repetir neste trabalho, as agências reguladoras tomam decisões importantíssimas para o futuro da sociedade, todavia, são destituídas de legitimidade para tanto, colocando em cheque a democracia a qual se encontra também ameaçada, infelizmente, pela atuação de outros Poderes, os quais desrespeitam a Constituição e a lei.

A partir desse tópico e em diante até a conclusão o que tentará se trazer é a forma de concretizar a atuação democrática nas agências, e mostrar que ao Judiciário há a possibilidade de servir de instrumento para a legitimação das agências reguladoras no Brasil.

Assim, deve-se ter em mente que este artigo parte-se do pressuposto de que a democracia deve estar presente em toda vida social e mesmo sabedor de que a democracia não seja um sistema perfeito, por ora é o melhor sistema que temos e mais, os valores e princípios elencados na legislação e em especial na Constituição nunca devem ser esquecidos e sempre devem nortear toda a sociedade, seja no âmbito dos poderes públicos, seja no particular, seja na atuação das agências reguladoras.

\section{A DESCENTRALIZAÇÃO ADMINISTRATIVA. O ESTADO E A SOCIEDADE}

Este tema foi escolhido para iniciar o presente artigo por um motivo, o fato de as agências reguladoras estarem na chamada Administração Indireta. Logo, para uma análise das agências reguladoras é inevitável não falar sobre descentralização administrativa.

A descentralização administrativa somente se fez presente quando o Estado passou a interferir mais na vida da população, por consequência, no Estado Liberal não há que se falar em descentralização administrativa, pois, conforme se estudará, neste Estado não era bem visto a intervenção estatal na vida social.

Pois bem, na proporção em que o Estado foi assumindo outros encargos e ficando cada vez mais presente na vida da população, tomando a frente no campo social e econômico, sentiu-se a necessidade de encontrar novas formas de gestão do serviço público e da atividade privada pela Administração, surgindo então o que se 
chama de descentralização administrativa.

Assim, dois objetivos da descentralização foram fundamentais, o primeiro foi a necessidade de especialização, pois é sabido que as relações sociais são diversas e complexas, logo quanto mais amplo for a atuação estatal mais genérica fica, quanto mais restrito mais especializado, então com a criação de pessoas descentralizadas buscou-se melhorar a atividade estatal com a especialidade. E a segunda foi a necessidade da utilização de métodos de gestão privada, a qual é mais flexível e mais adaptável.

Diante de todo o exposto pode-se entender a descentralização como fato administrativo que transmite atividades do Estado a determinada pessoa integrante ou não da Administração (CARVALHO FILHO, 2015, p. 356).

O professor José dos Santos Carvalho Filho é categórico em explicar o que seria a descentralização administrativa, fazendo a diferenciação com a centralização, ensina o renomado professor:

Exatamente nessa linha distintiva é que se situam a centralização e a descentralização. Quando se fala em centralização, a ideia que o fato traz à tona é o do desempenho direto das atividades públicas pelo Estado-Administração. A descentralização, de outro lado, importa sentido que tem correlação com o exercício de atividades de modo indireto. (2015, p. 473-474)

Continua concluindo que:

Nessa linha de raciocínio, pode-se considerar a existência de uma administração centralizada e de uma administração descentralizada, ambas voltadas para o cumprimento das atividades administrativas. Por via de consequência, já é oportuno observar, nestas notas introdutórias, que a denominada administração direta reflete a administração centralizada, ao passo que a administração indireta conduz à noção de administração descentralizada. (2015, p. 474)

Ainda é interessante consignar que há duas formas de descentralização, a por outorga que ocorre quando o Estado cria uma entidade e a ela transfere determinado serviço público e por delegação quando o Estado transfere o serviço por contrato ou ato unilateral. 
O presente estudo, aqui proposto, encontra-se na Administração Indireta, ou seja, perante todo este aspecto de especialidade e métodos de gestão, logo, deve-se ter em mente que as agências reguladoras em certo prisma encontram-se em uma atuação típica do Estado, servindo como uma longa mão especialista a certo assunto.

Assim, as agências reguladoras como autarquias especiais são parte da vasta gama de pessoas chamadas de Administração Indireta.

Interessante notar que as agências reguladoras possuem uma histórica ligação como ente descentralizado, verifica-se:

Nos Estados Unidos, desde o século XIX surgiram entes descentralizados, de função regulatória de atividades especificas. (JUSTEN FILHO, 2002, p. 134)

Ainda mais profunda que a descentralização administrativa encontra-se o tema do próximo tópico, a descentralização autárquica.

\section{UM POUCO MAIS A FUNDO. A DESCENTRALIZAÇÃO AUTÁRQUICA}

Antes de falar acerca do modelo do Estado brasileiro, aliás, antes mesmo de falar da origem da agência reguladora, deve-se pincelar acerca da descentralização autárquica, cujo tema irá inevitavelmente contribuir para mostrar a necessidade das agências reguladoras e executivas, sendo que no próximo tópico irá se fazer a diferenciação entre ambas.

A doutrina informa que com a evolução do modelo centralista (ou modelo napoleônico) de Administração Pública surgiu a necessidade de trazer maior autonomia no desempenho de parcela das atividades estatais pela Administração Indireta, visto que a mera criação de autarquia ou qualquer outra espécie de ente da Administração Indireta, não estava adiantando para desafogar o Estado e consequentemente trazer maiores benefícios à população (OLIVEIRA, 2003, p. 110-111).

Em outras palavras, buscou-se com a descentralização autárquica descentralizar ainda mais a descentralização administrativa, ou seja, ao trazer maiores autonomias tentou-se desafogar ainda mais o Estado. 
É contudo, necessário observar que a mera criação de autarquia ou de qualquer outra espécie de ente da Administração Indireta, sem que possua um grau de razoável autonomia para desenvolver suas atribuições, não torna o seu desempenho mais ágil e eficiente, não as caracterizando como entidades descentralizadas em sentido material, ou seja, efetivo, verdadeiro, constituindo, outrossim, entidades apenas formalmente descentralizadas. (ARAGÃO, 2002, p. 111)

Buscando então melhor servir a população, tentou-se trazer uma verdadeira descentralização administrativa, criando, para tanto, além das autarquias, as agências executivas e reguladoras, que acabaram por trazer maiores poderes às autarquias ou fundações públicas, fazendo com que o Estado tivesse menores atribuições e ao mesmo tempo munir tais entidades com maiores poderes, fazendo desafogar o primeiro.

Observa-se que a todo o momento sempre se buscou melhor satisfazer a sociedade, ou seja, não houve descentralização por descentralizar, mas sim descentralização para otimizar a atuação estatal.

Neste ideário, de servir a sociedade, é que se constrói toda a argumentação que irá se testilhar ao longo deste texto, consignando que, seja a agência executiva, seja a agência reguladora, seu objetivo é servir à população e não blindar abusos e interesses privados.

Em outras palavras, o interesse público presente na Administração Pública ainda irá nortear as agências executivas e reguladoras, não obstante estas terem ganhado maior poder.

\section{A DIFERENÇA ENTRE AGÊNCIAS EXECUTIVAS E REGULADORAS}

Após consignar o ponto bussolar do presente trabalho, interessante, neste momento, diferenciar as agências reguladoras e as agências executivas, deixando claro que, numa ou noutra, a finalidade pública ainda existe.

Pois bem, as agências executivas não são uma espécie de entidade é tão somente uma qualificação que poderá ser conferida pelo poder público às autarquias e às fundações públicas que celebrarem contrato de gestão e que atenderem aos requisitos fixados pela Lei no 9.649/1998. 
Ditos contratos de gestão são firmados entre o poder público e entidades da administração indireta ou órgãos da administração direta tendo como finalidade ampliar a autonomia gerencial, orçamentária e financeira, tendo como contrapartida a estipulação de metas de desempenho para a entidade ou o órgão cumprir.

Já as agências reguladoras além de ter tais autonomias possuem, como o próprio nome sinaliza, um amplo poder regulador.

De forma bastante didática Alexandre Santos de Aragão elenca as semelhas e diferenças de ambas as agências.

1. As agências reguladoras e as agências executivas, surgidas no Brasil no mesmo momento de mudança das estruturas administrativas tradicionais, hierarquizadas, apesar da semelhança de nomenclatura, constituem institutos diversos; 2. As agências reguladoras são entidades caracterizadas pelos largos poderes normativos que possuem em determinado setor, e pelas prerrogativas dos seus dirigentes; 3 . As agências executivas constituem mera qualificação dada a órgãos ou entidades da Administração Pública de qualquer espécie, que mantém a sua natureza originária e que, depois de celebrado o contrato de gestão com a Administração central, adquirem ou aumentam a sua autonomia gerencial; 4. A natureza das agências reguladoras decorre diretamente das suas respectivas leis instituidoras, dos poderes normativos e das prerrogativas funcionais nelas contempladas; 5. A qualificação como agência executiva é feita por ato do Poder Executivo central, dentro dos lindes da lei regulamentadora prevista no $\S 8^{\circ}$ do artigo 37 da Constituição Federal, norma constitucional de eficácia limitada; 6 . Destarte, a autonomia que um órgão ou entidade goze como agência executiva deriva do ato formal de sua qualificação como tal, não se confundindo com a mera garantia de certo âmbito de autonomia feita por lei ou por regulamento, fora dos parâmetros traçados pela lei regulamentadora do $\S 8^{\circ}$ do artigo 37 da Constituição Federal. (...) (2002, p. 121)

Dessa forma, por amor a brevidade, mesmo sem negar a importância do estudo das agências executivas, finaliza-se sua breve análise para a partir de agora passar a um estudo mais focado às agências reguladoras, trazendo uma análise histórica e sociológica das mesmas.

\section{ESTADO BRASILEIRO E REGULAÇÃO: BREVE EXCURSO HISTÓRICO E COMENTÁRIOS CRIITICOS}

Antes de chegar à conclusão se o Brasil é ou não um Estado regulador, necessário se faz, inicialmente, trazer ao presente trabalho alguns modelos de Estado que existiram ao longo da história, e, de 
forma quase que cronológica, analisar se esta Terra Tupiniquim chegou a ser um Estado regulador.

Assim, se apresenta no presente trabalho alguns breves comentários acerca do Estado Liberal, Social e Regulador, para só então, ao final, tentar responder a pergunta provocante deste tópico.

Inicia-se, então, na análise do Estado Liberal.

Ao se fala em Estado Liberal, é impossível deixar de pensar na sua função que foi a de garantir a propriedade e a liberdade do indivíduo frente ao Estado Absolutista.

Justifica-se este pensamento no fato de que na época vigia o ideário de que o Estado era o fantasma que atemorizava o indivíduo.

Com esta visão, a justificativa para toda e qualquer filosofia política ou jurídica se mostrava voltada para uma abstenção estatal em favor de uma liberdade de mercado, assim não diferente era a ideologia da separação dos poderes, a qual serviria de escudo aos direitos de propriedade e de liberdade.

Por esta razão que a doutrina informa que no Estado Liberal não haveria forte presença do elemento popular na vontade estatal, nem direito de todos a uma igualdade na participação da formação desta vontade, sendo que a "liberdade" no Estado Liberal é literalmente a negação da soberania estatal (ARAÚJO, 2010, p. 19).

Ora, nada mais justificável é este pensamento, visto que, como dito acima, o Estado era visto como fator maléfico da sociedade, logo, não haveria razões para a população querer tomar a frente da vontade estatal, mantendo suas esperanças num simulacro de salvador que seria o mercado.

Assim, buscava-se ao máximo a abstenção estatal para fortalecer o mercado, o qual possuía poderes quase que ilimitados.

O professor Paulo Bonavides (2008, p. 55) é enfático ao mostrar a inversão de papeis no absolutismo e liberalismo, pois, outrora, no absolutismo, o poder político do rei tinha ascendência sobre o econômico do feudo, já no liberalismo, o poder econômico do feudo teve ascendência sobre o poder político do rei, em suas palavras, "e o econômico (a burguesia) que inicialmente controla e dirige o político (a democracia), gerando uma das mais furiosas contradições do século XIX: a liberal-democracia”.

A história mostrou os problemas com o Liberalismo que começaram a surgir ante uma situação factual, pois a liberdade, que 
era fator determinante neste pensamento, era apenas formal, cujo resultado foi encobrir as desigualdades existentes na sociedade, que para Bonavides $(2008$, p. 61) "termina a apregoada liberdade numa real liberdade de oprimir os fracos, restando a estes apenas a liberdade de morrer de fome".

Neste momento, quando ainda reinava o Estado Liberal, a intervenção estatal era tão somente voltada para os interesses da classe dominante, sendo que o Estado apenas invadia na sociedade quando fosse conveniente para a massa.

Outro ponto interessante para se ressaltar é o fato de que a manifestação do Poder Legislativo era voltada, também, aos interesses da classe dominante, aliás, esse mesmo poder, era controlado pela burguesia, deixando a massa, vulgarmente numérica e não nos termos jurídicos-políticos, na situação de minoria, nos exatos termos jurídicos-políticos desta expressão.

A falsa ideologia que reinava no campo social e econômico de que havia um ciclo natural no qual o mercado por si só era suficientemente regulatório, não necessitando, dessa forma, da intervenção do Estado, cujo epíteto "mão invisível" da autoria de Adam Smith em sua obra The Wealth of Nations, resultou em uma separação absoluta entre os planos políticos e econômicos, cujos efeitos catastróficos na sociedade a história mostrou.

É dizer, acreditava-se na impossibilidade de que o campo político pudesse interferir no econômico e o econômico não interferir no político, aliás, antes mesmo de uma crença era um pressuposto regulatório.

De certo, sabe-se que é impossível a absoluta separação entre os planos políticos e econômicos, pois, no mínimo, se pensar que para o Estado se manter e desempenhar suas funções mais básicas, este deverá se incutir no plano econômico, ao menos no que tange ao recolhimento de tributos, e este fato, por si só, já mostra a falha lógica deste pensamento.

Pois bem, a ideologia da "mão invisível" aplicada na realidade social, o qual possuía o pressuposto da não intervenção, não pôde se concretizar em sua plenitude, pois a história acabou mostrando que o mercado econômico culminou nas chamadas falhas de mercado, ou seja, nas falhas de mobilidade, de transparência, de estrutura, de sinal e de incentivo. 
A imperfeição de funcionamento do mercado no Estado Liberal, que só aumentava as desigualdades e ressaltava os problemas sociais, fez com que a sociedade necessitasse do Estado na regulamentação do mercado, não apenas na tributação, mas de uma forma mais pró-ativa, tomando decisões como um verdadeiro agente econômico.

Ao ultrapassar o Estado Liberal, viu-se que a liberdade é ameaçada não somente pelo Estado, mas também pela própria sociedade desregulada (NUSDEO, 2005, p. 168), a qual, diga-se de passagem, por vezes é mais severa e voraz que um tirano no poder, pois a natureza humana por vezes se mostra mais individualista, egoísta e cruel quando experimenta uma liberdade na qual abre a possibilidade de reduzir o homem a mero objeto de suas vontades.

Em uma comparação simplista pode-se dizer que assim como está o servo para o tirano no Estado Absolutista, está o "neoescravoassalariado" para a indústria no Estado Liberal.

Ante a crise experimentada pelo Estado Liberal, abrolha o Estado Social, o qual se diferencia do Estado Proletário no sentido da mantença do regime capitalista, dando respeito à propriedade privada e à livre iniciativa, contudo sem dar o glamour que outrora o Estado Liberal os deu.

Este novo Estado possui como vantagem a sua adaptabilidade aos mais variados sistemas de organização política, visto que ante sua natureza plástica, pode ser instituído em sistemas democráticos e totalitários.

Assim, o Estado Social busca mitigar os conflitos sociais, trazendo um equilíbrio entre o trabalho e o capital. Para tanto cria diversos direitos do trabalho, da previdência, da educação, da saúde, da intervenção na economia como distribuidor, do estabelecimento de salários, estipulação de preços, combate ao desemprego e etc., limitando, assim, a autonomia privada do mercado.

Em outras palavras, o Estado Social estende sua influência a quase todos os domínios que antes pertenciam à área da iniciativa individual, mostrando que esses tipos de intervenções são benéficas para a sociedade e para a economia, veja, e.g., no livro "Desenvolvimento, Trabalho e Solidariedade", organizado por Marcio Pachmann, a análise da cidade de São Paulo-SP nos anos de 1990 a 2000 com as políticas públicas desenvolvidas pelo governo, 
os quais se mostraram como fator humanístico na qual realoca famílias e reconstroem sonhos, trazendo esperanças aos mais pobres que são aqueles que mais necessitam, fomentou, ainda mais o mercado, o qual se desenvolveu desde a base da sociedade.

Dessa forma, heroicamente, tenta o Estado Social sanar as distorções e injustiças causadas pela ausência de atuação do Estado Liberal na economia, fazendo conviver Estado e mercado.

Neste novo tipo de convivência a doutrina acabou denominando de sistema misto ou de iniciativa dual, na qual as tomadas de decisões econômicas se fazem com a presença do Estado, ocorrendo, assim, a superação dos modelos econômicos de autonomia, no qual o Estado era mínimo e exercia pouca influência sobre a produção e a troca de bens.

Todavia, a atuação do Estado Social não foi igualíssima em todos os países, pois naqueles que possuíam economia desenvolvida o Estado agiu no campo do bem-estar social, já nos de economia não desenvolvida concentrou-se em promover o desenvolvimento econômico.

Em outras palavras, nos países de Primeiro Mundo o setor decisório público é de cunho distributivo, já nos países em desenvolvimento o setor decisório público é voltado ao crescimento e à melhoria da produção.

Com a superação da extrema indiferença fez com que houvesse a extrema participação do Estado na economia, trazendo o problema em delimitar a fronteira entre as áreas próprias de cada um dos envolvidos, ou seja, onde deveria atuar o mercado e onde deveria atuar o Estado.

Assim, os teóricos da public choice ressaltaram as imperfeições nos seguintes pontos: a. princípios motores diversos: o setor privado foi estruturado sobre o princípio do hedonismo e, quando recebe o impacto regulamentador do Estado, é obrigado a se comportar contra aquele princípio, como ocorre quando pesada tributação lhe é imposta ou quando é obrigado a adotar medidas antipoluentes, ou, ainda, quando é levado a praticar preços abaixo daqueles tidos como de mercado; b. juridificação: fenômeno da multiplicação das normas legais e regulamentares cuja tendência é criar uma babel normativa, dificilmente absorvível pelo mercado, gerando crises de absorção, de má adaptação e de rejeição; 
c. captura: fenômeno no qual as exigências regulamentares passam a se amoldar às conveniências e interesses das unidades reguladas; $d$. interesses próprios dos reguladores; e. grupos de pressão; f. poder da burocracia.

Chega-se, neste momento em um questionário indutivo que seria: mas, afinal, o Brasil é um Estado Social ou Liberal?

Da análise da Constituição de 1988 verifica-se que o sistema econômico brasileiro é dual, ou seja, social.

Todavia, na última década do século $\mathrm{XX}$ houve $\mathrm{o}$ reaparecimento de ideais liberais, voltadas a conter a atuação do Estado, colocando o Estado no núcleo estratégico e nas atividades exclusivas do mesmo, já o mercado coloca-se no setor de bens e serviços.

Assim, surge a ideologia de que só deve ser estatal a atividade que não puder ser eficazmente controlada pelo mercado.

Neste momento, floresce um ponto de equilíbrio que seria o Estado Regulador.

Neste houve o entendimento de que não pode o Estado se abster da economia, mas também este não possui a capacidade de ser o centro da economia, visto que, ao Estado possui diversas responsabilidades e sendo ele inevitavelmente limitado não consegue prover tudo com a qualidade em que se espera, assim, no campo econômico não deve ser o agente principal, mas sim deve somente regulá-lo.

Em nossa sociedade, num primeiro momento, tentou-se regular a economia através da propriedade estatal, a qual se mostrou falha, assim passou-se para outra estratégia, deixando os serviços públicos nas mãos privadas, todavia, sujeitos a normas elaboradas pelo Estado. Além do mais, o Estado viu-se tão somente como regulador e não como agente econômico.

Deste modo, ficou presente a ideologia do Estado Regulador, no qual o Estado influi na economia com a proliferação de normas como meio de intervir na ordem econômica, surgindo, neste momento, as agências reguladoras, as quais são imbuídas na missão de editar normas para regular a economia.

Observa-se que tais agências foram escolhidas tendo em vista a complexidade do mercado econômico, sendo que, ao se instituírem as agências reguladoras a fazem cuidar de temas técnicos, buscando 
dar maior eficiência à regulamentação da economia pelo Estado.

Ante a inegável existência das agências reguladoras no Brasil pode-se afirmar, com efeito, que o Estado brasileiro é sim um Estado Regulador, pois ao longo das décadas o Brasil transferiu empresas que o era pertencente para o setor privado, fazendo com que o Estado diminuísse de tamanho em sua atuação econômica.

Prova disto é a Lei $n^{\circ} 9.491$ de 1997 , cujo artigo $1^{\circ}$ dispunha que o Programa Nacional de Desestatização se destinava a reordenar a posição estratégica do Estado na economia, transferindo à iniciativa privada atividades indevidamente exploradas pelo setor público.

Todavia, ao contrário do ideário de Estado Regulador, na prática o que se tem é um retrocesso ao laissez-faire, tendo uma regulação que mascara uma desregulação.

Outra modesta crítica é que não obstante a desestatização, a carga tributária ainda continuou elevada, é dizer, no Brasil se tributa como um Estado máximo e age como um Estado mínimo.

Cômico é pensar que a inspiração norte-americana que teve o Brasil para a criação das agências reguladoras que chancela um Estado Regulador, naquele país possuía finalidades diversas do que neste, pois segundo Binenbojm (2008, p. 272) o modelo norteamericano teve como fim a relativização das liberdades econômicas básicas, como o direito de propriedade e a autonomia da vontade, já no Brasil a finalidade foi assegurar a plenitude de tais direitos e evitar tentativas de mitigação dos mesmos por governos futuros, em suas palavras "era preciso vender o Brasil como um bom negócio, garantindo aos investidores a manutenção dos contratos celebrados e o direito de propriedade" (BINENBOJM, 2008, p. 273).

O problema deste plágio, além de ideológico, é que lá nos Estados Unidos historicamente a sociedade civil é organizada a ponto de atender a quase todas as suas necessidades, já no Brasil é ao revés, sua sociedade é amorfa e desorganizada necessitando do Estado para fazer frente às desigualdades e explorações do mercado econômico e dos agentes econômicos, ou seja, das massas.

Reflete-se: mas qual a razão do Estado Social ter falhado no Brasil? Se é que falhou!

O Estado brasileiro ao longo dos anos se tornou uma grande estrutura, com grande poder político frente a uma sociedade civil amorfa, com graus elevados de tributação, todavia, por conta da prática 
do patrimonialismo o modelo de Estado Social veio a coincidir com o anseio de alguns grupos familiares pela conquista de espaço público, detonando todo e qualquer planejamento teórico social.

Assim, por conta da cultura patrimonialismo desviou-se o atendimento de necessidades públicas e seguiu-se aos interesses privados, não surgiu outra escolha senão mudar-se para um sistema de Estado Regulador, todavia, a mesma cultura patrimonialista ainda encontra-se presente neste Estado, prova disto são as mazelas que as agências reguladoras, na prática, ocasiona, fazendo com que o Brasil na prática, infelizmente, se aproxime mais de um Estado Liberal do que um Estado Regulador, oprimindo cada vez mais seu povo, sua sociedade, seu consumidor.

\section{BREVE COMPARAÇÃO COM O MODELO AMERICANO}

Mesmo que brevemente, enriquece o presente trabalho trazer para a análise o modelo americano das independent agencies, visto que este serviu de inspiração para a criação das agências reguladoras no Brasil conforme já dito.

Pois bem, segundo Maria Salvador Martinez a origem das independent agencies remonta ao surgimento e expansão do sistema de transporte ferroviário, neste momento o Parlamento percebeu que era incapacitado em proporcionar um eficiente controle, tendo em vista a falta de conhecimento técnico sobre a matéria.

Assim, ante este fato começaram a surgir Comissões ad hoc, que no início tinham caráter não permanente, com a estreita finalidade de se promover não só a fiscalização, mas também uma assessoria na tomada das decisões parlamentares, ou seja, essas Comissões muniam o Parlamento com os dados técnicos que necessitavam (COSTA, 2011, p. 56).

Essas Comissões aos poucos foram tomando forma e se transformando no que hoje se conhece como independent agencies.

Desde o início verificou-se que no modelo americano, como já dito, as independent agencies surgiram com a finalidade (e necessidade) de limitar a autonomia privada, pois, naquelas empresas ferroviárias, as quais começaram a ser reguladas, reinava um grande descontentamento da população, tendo em vista que eram cobradas tarifas de forma ilimitada, bem como havia outras práticas abusivas dessas empresas. 
Dessa forma, as independet agencies buscavam trazer maior satisfação à população, limitando a autonomia privada das empresas de estrada de ferro, que outrora reinava de forma quase que ilimitada.

Logo, na sociedade americana, que se caracteriza por uma sociedade unida, as independet agencies viabilizaram um maior controle das empresas, visto que graças a esta união houve uma participação social dos interessados na tomada das decisões das independet agencies, ou seja, no caso americano vislumbra-se desde sua nascente uma participação democrática, resultando, em decisões com maior legitimidade.

Mas mesmo nos Estados Unidos, com toda sua participação popular e sua legitimidade resultante, houve críticas a respeito da legitimidade, em especial modo em razão da possibilidade da "venda" dos dirigentes das agencies.

Por tal motivo a doutrina e a jurisprudência passaram a questionar a legitimidade constitucional dessas instituições, por afronta ao princípio da separação dos poderes, levando o Congresso Americano a reduzir a discricionariedade das agências independentes, com a institucionalização de audiências regulares perante àquele órgão, a possibilidade de veto legislativo com relação a algumas de suas decisões e o estabelecimento de programas de ação e fixação de metas.

Dessa forma não há outra conclusão e observação a se fazer, a não ser reconhecer que se até mesmo em sociedades como a americana, cuja união popular e participação ativa dos cidadãos, por vezes, são dignos de exemplo, houve a necessidade de um maior controle nas agências reguladoras quem dirá na sociedade brasileira a qual encontrase, infelizmente, com um povo desunido e com um consumidor amorfo, logo, o tema do presente artigo ganha voz e suas críticas servem como parâmetro de retomada democrática da população.

\section{O EXERCÍCIO DA FUNÇÃO REGULATÓRIA E AS COMPETÊNCIAS DAS AGÊNCIAS REGULADORAS: LIMITES E SUPERAÇÕES}

Ao longo dos últimos tópicos buscaram-se trazer argumentos para a compreensão da forma em que se espera que uma agência reguladora deva atuar e mais, começou a mostrar a necessidade de 
uma retomada democrática da população em relação às agências reguladoras, demonstrando que mesmo em países como os Estados Unidos cuja população é mais ativa houveram no passado crítica sobre a legimidade e a necessidade de criarem instrumentos de controle social.

Assim, ciente de suas funções e das suas mais acirradas críticas, pode-se, agora, com um vasto conhecimento e visão crítica que o olha histórico trouxe ao leitor, procurar analisar como se deverá ocorrer o exercício da função regulatória.

Por ora, guardam-se as críticas para tópicos vindouros, sendo que o momento é de reflexão quanto ao exercício da função regulatória que as agências reguladoras possuem, procurando fixar seus limites e campos de atuação.

Dessa forma, neste tópico busca-se, além de compreender a função regulatória, procurar os seus limites e as suas competências regulatória das agências reguladoras, bem como se há a existência de competência normativa, em especial modo fazendo um contraste com o princípio da legalidade, cuja fundamentalidade é indiscutível em um Estado Democrático de Direito que o é o Brasil.

Desde já traz a crítica quanto a possibilidade de existência das agências reguladoras, pois, sabe-se que a Constituição tão somente fez previsão quanto a ANATEL (art. 21, XI) e a ANAP (art. 177, $\left.\S 2^{\circ}, \mathrm{III}\right)$, sendo que as demais agências somente possuem existência em normas infralegal, o que deixa ainda mais discutível a competência das mesmas, em especial não só sua formação, mas sim sua atuação como ente regulador e como eventual fonte normativa.

Pois bem, se é constitucional ou não a existência das agências reguladoras isto este trabalho não irá se adentrar, mas é fato que elas existem então passemos agora a discutir sobre a limitação normativa das agências reguladoras, seja a ANATEL e ANAP, sejam outras agências reguladoras como ANTT, ANVISA, ANAC e etc.

$\mathrm{Na}$ doutrina verifica-se que alguns autores defendem que a limitação do poder normativo das agências reguladoras encontra-se nos estritos limites definidos no art. 84, IV da CRFB/88, ou seja, são os mesmos limites impostos aos poderes regulatórios do Presidente da República.

Contudo, outros autores, a exemplo de Celso Mello (2004, p. 159), admitem maior liberdade no exercício do poder normativo 
pelas agências reguladoras, todavia, apenas quando se tratar de seu exercício no espaço da supremacia especial da Administração Pública, como por exemplo, nas condições dos serviços públicos concedidos.

Outro posicionamento é de Di Pietro (2002, p. 407) que defende que a produção regulatória deve se prestar a fiel execução da lei, entendimento este partilhado por nós, pois, conforme já sinalizado ao longo do texto e que será tratado em diversos tópicos abaixo, atualmente vive-se em um Estado de Direito cuja lei é a principal fonte de obrigações, não podendo, uma agência reguladora, que não possui legitimidade democrática inovar o ordenamento jurídico ao seu bel prazer.

Pois bem, tendo em vista o princípio constitucional da legalidade pode-se concluir que o limite do poder regulatório não se encontra no art. 84, IV da CRFB/88, pois, conforme argumentado no tópico acima, as agências reguladoras possuem uma finalidade regulamentar do mercado.

Contudo, essa função não é ilimitada, assim, com o arcabouço doutrinário que se extrai de ambos os autores acima citados pode-se chegar à conclusão de que não obstante existir certa margem de poder regulador, este, por conta do princípio da legalidade, encontrase limitado à proibição de inovação na ordem jurídica, ou seja, devese buscar o cumprimento da lei, pois esta que se encontra legitimada democraticamente.

Assim, sabedor destas premissas tem-se que as determinações normativas deverão ter aspectos estritamente técnicos, não havendo, jamais, delegação legislativa (CUÉLLAR, 2008, p. 58), ou seja, as agências reguladoras jamais podem inovar o ordenamento jurídico, deve tão somente complementar a lei com questões de ordem técnica.

Interessante a conclusão que Binenbojm (2008, p. 285) chega ao afirmar que o poder normativo das agências reguladoras só podem apresentar natureza regulamentar infralegal, sendo uma técnica da deslegalização.

Todavia, como adverte Sérgio Varella (2003, p. 116) a lei deve estabelecer no mínimo os princípios a serem seguidos e os objetivos a serem atingidos, o alcance e os limites dos poderes conferidos à Administração de forma a possibilitar um mínimo aceitável de 
controle sobre a atividade regulamentar, pois sem estes parâmetros fica complicado em saber até onde começa a questão de ordem técnica e quando se apresenta subjetivismo inovador da ordem jurídica.

Logo, a atividade regulamentar das agências reguladoras consiste em procurar trazer a "fiel execução da lei", como dito sabiamente por Di Pietro, cuja "lei" não se resume somente na lei que institui a agência, mas em todo o ordenamento jurídico, em especial modo a Constituição.

Não se pode perder de vista que para se ter a "fiel execução da lei" antes de tudo deve-se haver uma interpretação desta "lei", e esta mesmo que se busque a maior objetividade possível sempre haverá um mínimo de subjetividade de quem a interpreta, em outras palavras, na atividade regulatória inexoravelmente haverá um resultado que não será igualíssimo aos ditames legais, pois, a subjetividade do intérprete poderá fazer com que ganhe nova forma a interpretação, fazendo da criatura ser diverso do criador.

Por esta razão os princípios neste ponto se tornam grandemente eficazes, pois trarão os objetivos e pensamentos dogmáticos acerca da matéria, e mesmo quando se tratar de ordem técnica, os princípios poderão nortear as escolhas feitas pelas agências.

Por exemplo, na modesta opinião deste autor, a regulamentação do BACEN além de vislumbrar a regulamentação do mercado financeiro e bancário deve, ao fazer seus regulamentos, ter a noção que haverá relações de consumo, em especial de crédito, assim, nunca pode perder de vistas o objetivo protetor do CODECON, pois a lei traz balizas e objetivos que o Estado tenta buscar, aliás, quando não, a própria Constituição traz esses objetivos do Estado que muitas vezes são ainda mais protetores que leis infraconstitucionais.

Outro exemplo, mas este tirado da jurisprudência, é extraído do Tribunal Regional Federal da $4^{\mathrm{a}}$ Região, quando esse tribunal analisou a aplicação da resolução da ANVISA em seguinte situação, na criação da Resolução da Diretoria Colegiada (RDC) $n^{\circ} 33$ de 2000, revogada pelas RDCs n 214 de 2006 e no 67 de 2007.

Sabe-se que a ANVISA é uma agência reguladora, vinculada ao Ministério da Saúde, tendo por finalidade promover a proteção da 
saúde da população, por intermédio do controle sanitário da produção e da comercialização de produtos e serviços submetidos à vigilância sanitária, incluído dos ambientes, dos processos, dos insumos e das tecnologias a eles relacionadas, além do controle dos portos, aeroportos e de fronteiras, nos termos da Lei $\mathrm{n}^{\circ} 9.782$ de 1999.

$\mathrm{O}$ art. $7^{\circ}$, III, da Lei $\mathrm{n}^{\mathbf{0}}$ 9782/99, por exemplo, prevê competência normativa para a Agência Nacional de Vigilância Sanitária - ANVISA, ao colocar que referida entidade poderá estabelecer normas, propor, acompanhar e executar as políticas, as diretrizes e as ações de vigilância sanitária; o inciso XVIII, por sua vez, permite a ANVISA "estabelecer, coordenar e monitorar os sistemas de vigilância toxicológico e farmacológico".

Pois bem, na Apelação Civil no 2006.70.00.013961-4 (AC 13961/PR), o Tribunal Regional Federal da $4^{\mathrm{a}}$ Região considerou ilegal que, embora a Agência Nacional de Vigilância Sanitária tenha competência para normatizar, controlar e fiscalizar produtos e serviços de interesse para a saúde pública, a Resolução RDC $n^{\circ} 33 / 2000$ criasse restrição indevida ao limitar a participação de farmácias de manipulação em licitação públicas. O item 5.10 da Resolução RDC no 33/2000 vedava à farmácia de manipulação habilitar-se em licitação pública para o fornecimento de medicamentos manipulados, quando houvesse disponível no mercado especialidade farmacêutica semelhante.

Nota-se, assim, que é corriqueiro os abusos que as agências reguladoras fazem ao normatizar indo além do que determina a lei, inovando o ordenamento jurídico.

De forma a resumir, as agências reguladoras se encontram em um meio termo entre aplicar a lei e criar normas, veja que elas não podem se desgrudar dos objetivos da lei, todavia vai muito além da simples aplicação desta, pois, conforme já dito no tópico acima quando se falou no início da criação das independet agencies, as agências reguladoras (ou no modelo americano, agências independentes) possuem conhecimentos técnicos que o próprio Poder Legislativo não possui, por esta razão, ante sua inegável atividade quase normativa, a atividade das agências reguladoras acabam por se aproximarem a dos juízes do Common Law.

Interessante, novamente, o posicionamento, agora um pouco 
mais alargado, de Maria Sylvia Zanella Di Pietro (2011, p. 483-484) que aponta, portanto, que a produção de normas jurídicas pelas agências reguladoras deverão se pautar apenas na regulação da própria atividade da agência por meio de normas de efeitos internos; e na conceituação, interpretação, explicação de conceitos jurídicos indeterminados contidos em lei, sem, contudo, inovar no sistema jurídico.

Nesta comparação com os juízes do Common Law, contribui como forma a complementar o estudo as posições de Justen Filho (2002, p. 364) que sabedor desse subjetivismo, afirma que as decisões técnicas das agências reguladoras refletem escolhas políticas, logo, o mesmo autor diz que a atuação das agências reguladoras é permeada de relevância político-econômica, o que acarreta a ausência de neutralidade científica.

Isto reforça ainda mais o que se pretende defender neste trabalho, ou seja, a necessidade da tomada democrática deste poder "normativo regulamentar".

Enfim, pode-se concluir pela inexistência de um caráter objetivo nas escolhas das agências reguladoras, todavia, estas não possuem o poder de legislar, tampouco legitimidade democrática para inovar o ordenamento jurídico, mas atuam, como os juízes consuetudinários, numa criação sem inovação que nada mais é que um complemento técnico da lei, sem se descuidar dos objetivos basilares da legislação, ou, melhor, de todo o ordenamento jurídico que vai desde a Constituição até as leis, aliás, é isto que se espera.

Sabendo os limites e os objetivos do poder regulamentar das agências reguladoras uma crítica deve-se deixar consignada, qual seja, a falta de mecanismos de controle efetivo fazem com que não há como garantir que as agências reguladoras desempenhem seu papel nos limites e objetivos da lei havendo a necessidade do povo recuperar seu poder democrático e talvez um caminho seja encontrar no Poder Judiciário um instrumento para o empoderamento da sociedade.

Isto demonstra a complexidade do controle da atividade normativa das agências reguladoras, pois se sabemos que há uma certa liberdade para criação ante ao fato da inexistência de um caráter objetivo, fica a indagação, como poderemos controlar sua normatividade, sendo que, na prática, infelizmente, verifica-se a 
necessidade deste controle? Pois não raras as vezes a atividade regulatória é uma forma de mascarar a subversão da classe dominante frente a classe dominada.

Inegável, assim, a necessidade de empoderamento da sociedade que deverá fazer frente a este "novo" Estado Liberal prático.

\section{A SUTIL DIFERENÇA ENTRE FUNÇÃO REGULAMENTAR E FUNÇÃO REGULADORA}

Interessante trazer neste trabalho, ou tentar trazer, a diferença entre função regulamentar e reguladora, todavia, deixa-se consignado desde já que o se busca defender no presente estudo é sempre a necessidade de tomadas de decisões democráticas pelas agências reguladoras de modo a trazer-lhes maior legitimidade em sua atuação, e mais, busca-se refutar toda e qualquer forma de abuso no qual põe o empresário acima da sociedade fazendo com que haja uma verdadeira blindagem de abusos econômicos.

Pois bem, a função regulamentar denota uma ideia de normatizar, quando visto pela ótica do Poder Executivo a função regulamentar nada mais é do que a produção de regulamentos (resoluções, instruções, portarias e regimentos), neste sentido José Carlos Francisco (2009, p. 209-211) diz que a função regulamentar não abrange a produção normativa conferida pela constituição aos demais poderes ou entes a ele vinculados, ainda que habilitados de competência normativa para pormenorizar a própria ordem constitucional ou leis que lhes sejam pertinentes, ou seja, a função regulamentar é definida como atividade normativa exercida exclusivamente pelo Executivo perante norma produzida pelo Poder Constituinte ou pelo Poder Legislativo.

Por conta disto é que acertadamente Dirley da Cunha Junior (2010, p. 87) diz que o regulamento é ato normativo secundário ou derivado, pois se baseia sempre na lei, a qual é ato normativo primário ou originário.

Assim, pode-se concluir que a função regulamentar é o dever de detalhar, especificar e atribuir real execução às leis - obviamente com aquela complementação de ordem técnica que a faz se distinguir de uma mera execução - ou disciplinar matérias que não são restritas 
à reserva legal, mas sempre buscando harmonia com todo o ordenamento jurídico.

Já a função reguladora também busca detalhar o conteúdo da lei, todavia, este não se aplica de forma restrita ao chefe do Executivo Federal (SOUTO, 2008, p. 03).

Todavia, não obstante as agências reguladoras tenham função regulamentar ou reguladora deve-se ter em mente que esta função sempre deverá respeitar a lei e a Constituição buscando sempre sua fiel execução, não servindo de norma jurídica primária, mas tão somente de detalhamento técnico, assim, passa-se para o próximo tópico no qual irá refletir quanto à formulação dessa "normatividade técnica".

\section{A NECESSIDADE DE PARTICIPAÇÃO DEMOCRÁTICA NA ATIVIDADE REGULATÓRIA DAS AGÊNCIAS REGULADORAS: POR UMA DEFESA DA DEMOCRACIA PARTICIPATIVA}

Conforme largamente exposto no presente trabalho, a atividade das agências reguladoras possui um caráter regulamentar e ao mesmo tempo quase normativo e, inegavelmente, influem de sobremaneira na sociedade, motivo pelo qual deve haver a necessidade de uma atuação democrática na expedição de seus regulamentos, visto que sua função social é deveras influenciadora nas relações privadas.

Atualmente, verifica-se uma produção de regulamentos pelas agências reguladoras, as quais nem sempre respeitam os princípios constitucionais e a legislação, praticando verdadeiros abusos, fazendo com que haja ainda mais a necessidade de uma participação democrática em suas atividades.

Dessa forma, cada vez mais se questiona a respeito de sua legitimidade, isso porque numa democracia é princípio basilar que as decisões mais importantes para os destinos da sociedade sejam tomadas por representantes eleitos e, no caso em estudo, as agências muitas vezes interferem mais na vida das pessoas do que a própria legislação.

Assim, questiona-se, há respeito à legitimidade democrática, quando as agências reguladoras regulamentam? E suas tomadas de 
decisões, será mesmo que respeitam todo o ordenamento jurídico? Será que não haveria necessidade de uma atuação democrática nas agências?

Para responder esses questionamentos relembre-se que as agências reguladoras possuem amplos poderes, cujos não são atrelados de forma objetiva à lei, e que elas direcionam a sociedade e muitas vezes possuem até mesmo o caráter redistributivo. Nesta última situação basta lembrar na gestão de serviços públicos, mormente na fixação de tarifas a serem praticadas pelos concessionários prestadores do serviço.

Em nossa modesta visão, da forma em que se encontram as agências reguladoras hoje, a sua autonomia e independência representa sim uma ameaça ao interesse público e à democracia, visto que pessoas não eleitas acabam tomando decisões relevantes para a sociedade e pior o controle de tais decisões por vezes não se mostram eficiente e em muitos casos até mesmo o judiciário se curva frente às Portarias de uma ANATEL.

No mesmo sentido, novamente Justen Filho (2002, p. 36) diz que a ausência de legitimidade democrática das agências reguladoras pode conduzir a desvios na regulação. Algo que infelizmente se verifica corriqueiramente na prática.

Ora, sob o manto da produção de regulação fundada apenas em considerações técnicas, as agências reguladoras acabam por comprometerem a legitimação política das decisões adotadas, afastando, assim, o princípio da soberania popular, resultando, dessa forma, no surgimento de núcleos de poderes infensos à influência das escolhas dos governados e, repita-se, por conta disto há a necessidade da retomada do poder decisório pela sociedade.

Por estas razões entendemos que há a necessidade de uma maior participação popular e a criação de mecanismos democráticos para a regulação, tema isto que será debatido em tópico oportuno.

Pode-se contrargumentar no sentido de que há sim participação popular, todavia a prática mostra que a participação se dá muito mais pelas grandes empresas, tornando ainda mais antidemocrático a atividade das agências reguladoras.

Outro problema para as decisões democráticas das agências surge no tocante aos assuntos que são tidos e a falta de informação acessível à população, pois esta não possui uma consultoria 
especializada que a possibilitaria a proceder em sua defesa. Exemplo disto é na elaboração de tarifas, uma única pessoa ante à massa de informações técnicas não conseguirá ir de encontro à elaboração de altas tarifas, restando, portanto, acatar uma decisão que lhe interfere de sobremaneira em sua vida sem a legitimidade esperada de um Estado Democrático de Direito.

Portanto, não é outra conclusão a não ser que falta à sociedade meios eficazes para combater as normas reguladoras, e infelizmente as agências reguladoras que deveriam servir a sociedade acaba servindo os setores regulados em detrimento do consumidor, se transformando, assim, um escudo de ilegalidades e ilegitimidades praticados por aqueles.

Logo, inegavelmente há a necessidade de uma participação mais democrática nas tomadas de decisões, pois, conforme notoriamente sabido, as agências reguladoras interferem de forma intensa na sociedade, e tendo uma atividade quase normativaregulamentar que acaba produzindo até mais que o próprio Legislativo e interferindo, dessa forma, em certos setores de forma mais voraz que este poder, sendo que alguns autores a exemplo de Bowers diz que a crescente atividade normativa das agências reguladoras acaba até mesmo ameaçando o Poder Legislativo como fonte principal de normas (ARAÚJO, 2010, p. 88).

Veja que essa preocupação mesmo que recente em nosso país encontra-se há muito em outros, a exemplo da Pensilvânia que começou a adotar o rules review quando os cidadãos passaram a perceber que as normas regulatórias afetavam mais as suas vidas do que a edição de uma lei (ARAÚJO, 2010, p. 96).

Assim há uma necessidade extrema de trazer mecanismos de participação popular, empoderando, dessa forma, a sociedade e democratizando as agências reguladoras.

\section{O CONTROLE LEGISLATIVO E EXECUTIVO NAS AGÊNCIAS REGULADORAS}

Infelizmente o controle nas agências reguladoras pelos Poderes Legislativos e Executivos se encontram aquém do esperado, fazendo nascer a necessidade de uma atuação do Poder Judiciário para o efetivo controle. 
Os controles dos Poderes Legislativo e Executivo incidem essencialmente na nomeação e na demissão dos dirigentes das agências, não se protraindo com mais vigor na própria atuação das agências. É aí que se configura necessário o crivo judicial sobre o desempenho eficiente dessas agências, já que os demais controles políticos se limitam especialmente ao ato de nomeação e destituição. (OLIVEIRA, 2003, p. 75)

Concorda-se com a posição e crítica do Professor Fernando de Brito Alves que afirma que:

Ainda, concluímos considerando que atribuir exclusivamente a juízes constitucionais o papel de controlar a constitucionalidade das leis (decidir sobre controvérsias morais) é desprezar o sentido primordial da democracia, que consiste na inexistência de hierarquia entre os integrantes da comunidade política. É necessário, por isso, maximizar o direito de participação, por meio do partilhamento da faculdade de interpretar a Constituição, hoje monopolizado pelo judiciário. Isso poderia contribuir para o desenvolvimento de uma comunidade política aberta, na qual a articulação entre o Estado e os movimentos sociais, constitua algo genuinamente novo e substantivamente democrático. (2012, p. 338)

Todavia o controle judicial, por medida inicial, seria a melhor solução a fim de empoderar a sociedade e trazer maior controle de legitimidade à atuação das agências reguladoras, tema este que melhor será testilhado no próximo tópico.

\section{O CONTROLE JUDICIAL DA ATIVIDADE REGULADORA}

Marco bussolar deste tópico é a ideia de inafastabilidade da jurisdição a qual encontra-se como uma garantia constitucional para todos, garantindo que o cidadão acione o Judiciário quando haja conflito entre ele e a Administração e entre os indivíduos de forma isolada.

Ora, se grande gama da atuação estatal é suscetível ao controle judicial nada é de se estranhar que a atuação da agência reguladora também o seja. 
Com isto na prática se mostra que graças à atual facilidade do acesso à jurisdição armam a população com a possibilidade de impugnar de forma individualizada a aplicação concreta de atos regulatórios de caráter normativo.

Note-se que com uma atuação do judiciário acaba ao menos em amenizar a falta de legitimidade das normas regulatórias, pois, o poder judiciário se torna uma ponte da sociedade para o Estado.

Obviamente que as críticas desse certo controle, conforme retrata Ortiz (1999, p. 613), reside no fato da falta de conhecimento técnico do juiz, mas cuja solução encontraria na criação de um único órgão judicial tecnicamente habilitado para conhecer as impugnações aos atos das agências reguladoras.

De forma singular Marçal Justen Filho ressalta:

Quando se cria uma agência e se lhe deferem determinadas competências, impõe-se-lhe o dever de definir a política pública que adotará. Essa política terá de ser compatível com a disciplina legislativa vigente, precisamente porque se trata de competência discricionária. Ademais disso, a fixação da política pública tem de refletir-se nos atos subsequentes, de cunho normativo abstrato ou concreto, praticados pela agência. Ou seja, poderá realizar-se o controle judicial também da coerência e da compatibilidade dos atos derivados, em face das políticas públicas escolhidas pela agência. (2002, p. 590).

Logo, o judiciário poderá se transformar como uma forma de controle efetivo de eventuais abusos que as agências reguladoras cometerem, nas palavras de Marcelo Carvalho Cavalcante de Oliveira "na verdade, toda instituição dotada de poderes mais alargados tende a exorbitar e, para que seja contida essa propensão natural, há que ser aprimorado o controle dos seus atos" (2003, p. 73).

Assim, através do controle judicial se arma não o judiciário em si, mas a quem realmente deve residir a legítima fiscalização de todos os Poderes, a sociedade. Pois, em um Estado Democrático de Direito todas as instituições devem prestar contas à população.

Note-se que as agências reguladoras pretendem furtar-se dos controles judiciais alegando razões técnicas, afirmando, para tanto, que caberia ao Judiciário tão somente examinar aspectos procedimentais. 
Pretendem as agências usar a proclamada autonomia para bem conduzir e os setores que lhe são correlatos, e escolher a solução mais adequada ao bem comum. Daí se dizer que precisam ficar relativamente imunes aos excessivos controles, sob pena de inviabilizar seus propósitos. Porém, não se pode esquecer que a sociedade organizada, seus representantes políticos e suas instituições formalmente constituídas são instrumentos legítimos de definição e operacionalização das políticas públicas mais consentâneas aos interesses coletivos. Portanto, equivocada a suposta absorção pela agência da exclusiva legitimidade de escolha das políticas a serem adotadas no setor respectivo. (OLIVEIRA, 2003, p. 77)

Assim, conclui-se que a atuação do judiciário ao controle dos atos das agências reguladoras é trazer ponto a mais para a democracia, em especial modo quando este atua para adequar os regulamentos à lei.

Como por exemplo, veja a atuação do judiciário em desconsiderar os regulamentos da ANATEL:

TJSP. Prescrição. Prazo. Ação de cobrança. Prestação de serviços de telefonia. Direito obrigacional pessoal. Matéria de competência legislativa da União, regrada pelas normas dos artigos 205 e seguintes do Código Civil. Impossibilidade de alteração, por resolução da ANATEL, dos prazos legais estabelecidos pela legislação ordinária. Recurso provido para acolher a pretensão da empresa de telefonia. (TJSP, $31^{\text {a }}$ CâmDirPri, Apelação 1191480800, Rel.: Des(a). Paulo Celso Ayrosa Monteiro de Andrade, 15/02/2011).

Dessa forma, deve-se ter em mente a atuação instrumental do judiciário para conferir maior legitimidade e proteção da sociedade frente a eventuais abusos das agências reguladoras.

\section{A RETOMADA DO POVO DO PODER DEMOCRÁTICO}

Todo poder emana do povo! Este é um pressuposto rousseauniana que nunca deve ser esquecido, logo para toda normatividade e regulamentação da sociedade deve estar munida de legitimidade democrática.

Assim, num Estado Democrático o povo jamais pode ser visto como objeto de dominação, mas sim como fonte de legitimação dos 
atos praticados, não sendo suficiente a mera representação nos poderes, pois há a necessidade de maior participação popular no Estado.

Dessa forma, consideramos que para a realização de projetos contemporâneos de democracia é mister que haja uma reserva clara de poder do povo. Se todo ele é alienado nas dinâmicas dos processos de representação, ou se o povo/multidão/bando dele é alijado pelas perversas dinâmicas de exploração do capitalismo, a aporia da democracia desnatura-se em devaneios metafísicos mais abstratos que o reino dos céus ou o Estado comunista. (ALVES, 2012, p. 306).

Por óbvio, e se escreve este tópico só para deixar consignado, que não é tão somente através do judiciário que se irá conquistar legitimidade democrática às agências reguladoras, mas também não se nega sua potencial função instrumental.

Mas da mesma forma que o professor Fernando de Brito Alves traz formas de maior empoderamento da sociedade, aqui também há como, ao menos que de ideologia, trazer algumas formas de participação social.

Assim, deve-se desenvolver mecanismos como consultas públicas, audiências públicas, denúncias e a ouvidoria, para funcionarem como meios viáveis de participação democrática do cidadão na produção normativa das agências.

Mesmo existindo esse tipo de mecanismos, estes além de não vincularem a autoridade reguladora se mostra, como já dito, totalmente desvirtuado, sendo certo que sua participação muitas vezes é antidemocrático, pois não mune a população com informações necessárias para o real entendimento da regulamentação buscada pelas agências reguladoras.

Deste modo deve-se democratizar os instrumentos para da democracia.

\section{CONCLUSÃO}

Após uma longa análise do tema proposto, com as pequenas conclusões trazidas ao longo do texto, neste momento há a possibilidade de se trazer um final para o presente artigo o qual tem a 
pretensão de armar o leitor do norte para argumentação em questões de ordem prática, assim, como dito desde o início, o caso prático terá o encargo de trazer a verdadeira conclusão do presente artigo.

Ao longo do texto percebeu-se que a descentralização administrativa e autárquica foram ferramentas trazidas pelo Estado com o fim de especializar sua atuação e trazer maior agilidade para o Estado, cuja burocracia e morosidade é notoriamente conhecida.

Assim, as ferramentas de descentralização, administrativa ou autárquica, sempre tiveram por escopo a função de procurar melhor servir a sociedade.

Em especial a segunda é que reside as agências reguladoras, pois, conforme se disse, a descentralização autárquica busca munir de maiores poderes os entes da Administração Indireta.

Notadamente, ante a esta intervenção do Estado, pode-se afirmar com segurança que o Brasil não é um Estado Liberal, e mais, o tópico 04 foi categórico em demonstrar a necessidade de uma atuação do Estado na sociedade brasileira.

Assim, ante a inegável existência das agências reguladoras, pode-se dizer que o Brasil buscou-se evoluir para um Estado Regulador, dessa forma, jamais as agências devem ser pensadas como forma de blindar certos ramos empresariais, elas servem a população.

Pensar de forma diversa é retirar toda a ideologia de um Estado Regulador.

Todavia, infelizmente, o que ocorre na prática é uma desregulamentação, isto acontece por conta de uma cultura patrimonialismo, a qual desviou o foco das necessidades públicas e para interesses privados, tornando o Brasil em um Estado Liberal sem regulação alguma.

Nisto que encontra-se a principal crítica deste artigo, na desregulamentação e na blindagem que se vê na prática.

Dessa forma tem-se um problema e um pressuposto. $\mathrm{O}$ problema é de ordem prático, qual seja, a desregulamentação e o pressuposto é de ordem teórica, ou seja, a presunção de que a atuação das agências reguladoras servem a sociedade.

Chega-se agora no segundo problema, qual seja, saber qual deve ser a limitação de atuação das agências reguladoras.

Pois, bem, conforme todo o analisado e sem perder de vistas o 
pressuposto teórico, tem-se que as agências reguladoras, não obstante tratarem de questões de ordem técnica, deve se ater à execução da lei e da Constituição.

Desse modo, sempre que um ato regulamentar que à título de trazer especificações técnicas ir de encontro à lei, deverá ser anulado.

Isso não quer dizer que as agências devem copiar a lei, mas sim que na sua regulamentação deve ir ao encontro da lei e da Constituição, fazendo muito próximo do que os juízes do common law fazem.

Assim, por conta dessa limitação é que surge o problema em delimitar a atividade reguladora, pois não raro ela ultrapassa os limites ao inovar o ordenamento jurídico.

A terceira crítica se funda na falta de controle efetivo, este se dá tendo em vista a impossibilidade do cidadão em questionar de forma eficaz as regulações das agências.

A quarta crítica se funda na falta de legitimidade democrática, pois, sabe-se que as agências reguladoras produzem as vezes mais que o próprio Legislativo, interferindo na sociedade de forma ímpar, todavia, mesmo tomando decisões para o futuro da sociedade, esta se dá de forma não democrática.

Assim, fica a questão se há a necessidade de se trazer maior legitimidade democrática para as agências reguladoras?

Crê-se que há a necessidade e a possibilidade através da participação popular que poderá ver no judiciário uma ponte de acesso às regulamentações, todavia, não se nega que deveria ter outros mecanismos e que infelizmente o judiciário não se mostra como instrumento, mas de forma utópica, numa mudança de paradigmas, tem essa casa do povo o poder de democratizar a democracia nas agências reguladoras.

\section{REFERÊNCIAS}

ALVES, Fernando de Brito. A construção histórica-discursiva do conteúdo jurídico-político da democracia como direito fundamental. Tese de doutorado da ITE, 2012.

ARAGÃO, Alexandre Santos de. Agências reguladoras e agências executivas. In: R. Dir. Adm., Rio de Janeiro, 2002. 
ARAUJO, Luiz Eduardo Diniz. Controle da atividade normativa das agências reguladoras. Dissertação UFPE, 2010.

ARIÑO ORTIZ, Gaspar. Principio de derecho público econômico: modelo de Estado, gestión pública, regulación económica. Granada: Comares, 2004.

BINENBOJM, Gustavo (coord.). Uma teoria do direito administrativo. Rio de Janeiro: Renovar, 2008.

BONAVIDES, Paulo. Do Estado liberal ao Estado social. São Paulo: Malheiros, 2008.

BRUNA, Sérgio Varella. Agências reguladoras: poder normativo, consulta pública, revisão judicial. São Paulo: Revistas dos Tribunais, 2003.

CARVAlHO FILHO, José dos Santos. Manual de Direito Administrativo. São Paulo: Atlas, 2015.

CASSESE, Sabino. Le autorità indipendenti: origini storiche e problemi odierni. In: CASSESE, Sabino; FRANCHINI, Claudio (Orgs.). I garanti delle regole: le autorità indipendenti nel sistema istituzionale italiano; i loro compiti normativi, amministrativi, giurisdizionali. Bolonha: Il Mulino, 1996.

COSTA, Angélika Souza Veríssimo da. O Princípio da Legalidade e os limites da produção normativa das agências reguladoras brasileiras. Dissertação da UFPE, 2011.

CUÉLLAR, Leila. Introdução às agências reguladoras brasileiras. Belo Horizonte: Fórum, 2008.

CUNHA JÚNIOR, Dirley da. Curso de direito administrativo. Salvador: Juspodivm, 2010.

DI PIETRO, Maria Sylvia Zanella. Direito administrativo. São Paulo: Atlas, 2002.

ENGISCH, Karl. Introdução ao pensamento jurídico. Lisboa: Fundação Calouste Gulbenkian, 2008.

FERREIRA FILHO, Manoel Gonçalves. Reforma do Estado: O papel das agências reguladoras e fiscalizadoras. In: Agências Reguladoras. São Paulo: Atlas, 2002.

FRANCISCO, José Carlos. Função regulamentar e regulamentos. Rio de Janeiro: Forense, 2009.

JUST, Gustavo. O Princípio da Legalidade Administrativa: O Problema da Interpretação e os Ideais do Direito Público. In: BRANDÃO, Cláudio; 
CAVALCANTI, Francisco; ADEODATO, João Maurício (coord.). Princípio da legalidade: da dogmática jurídica à teoria do direito. Rio de Janeiro: Forense, 2009.

JUSTEN FILHO, Marçal. O direito das agências reguladoras independentes. São Paulo: Dialética, 2002.

Dialética, 2002.

O Direito das Agências Reguladoras Independentes. São Paulo:

LA SPINA, Antonio; MAJONE, Giandomenico. Lo Stato regolatore. Bologna: Il Mulino, 2000.

MELlO, Celso Antônio Bandeira de. Curso de direito administrativo. São Paulo: Malheiros, 2004.

NUSDEO, Fábio. Curso de economia: introdução ao direito econômico.

São Paulo: Revista dos Tribunais, 2005.

OLIVEIRA, Marcelo Carvalho Cavalcante de. O controle judicial das Agências Reguladoras. Dissertação de mestrado da UFPE, 2003.

POCHMANN, Marcio. Desenvolvimento, Trabalho e Solidariedade: novos caminhos para a inclusão social. São Paulo: Cortez, 2002.

SOUTO, Marcos Juruena Villela. Função regulatória. In: REDAE, 2008. 